\title{
Studies of Hereditary-Obese Mice (obob) after Implantation of Pancreatic Islets in Millipore Filter Capsules
}

\author{
R.L. STRAUTZ
}

\author{
Department of Biology, The American University, Washington D.C., USA
}

Summary. Obese mice were implanted with Millipore diffusion chambers containing islets isolated from pancreas of normal littermates. Controls in this study were either obese implanted with encapsulated obese islets and empty chambers or non-obese implanted with encapsulated obese islets, non-obese islets and empty chambers. - Regular checks were made on all mice for weight gains and glucose levels. In addition, samples of blood were pooled from each group for immunoreactive insulin determinations. All mice, except one-half the experimental group, were sacrificed at 45 days and post-mortem examinations performed. The capsules containing non-obese islets were removed from the remaining obese mice and weight gains followed for an additional 45 days. These mice were then sacrificed and determinations made for glucose and insulin levels. - The results showed that woight gain was stabilized, glucose and insulin levels in obese mice were reduced within 14 days after implanting Millipore diffusion chambers containing non-obese pancreatic islets. Weight gain resumed immediately and elevated glucose and insulin levels were found 45 days after removing Millipore diffusion chamber. - These results led to the following conclusions: 1 . The spontaneous obesity which develops in the hereditary obese mouse results from a missing or defective pancreatic islet factor or factors. - 2. This factor originates from the islets of Langerhans and is capable of passing through $0.45 \mu$ pores of the Millipore membrane. - 3. This factor's presence is necessary for normal glucose and lipid metabolism and insulin sensitivity.

Etude de la souris obob après implantation d'v̂lots pancréatiques dans des capsules Millipore

Résumé. Des chambres à diffusion. Millipore contenant des îlots isolés de pancréas d'animaux normaux ont été implantées à des souris obèses. Dans cette étude, les animaux témoins étaient soit des animaux obèses implantés avec des îlots encapsulés d'animaux obèses ou avec des chambres vides, soit des animaux non-obèses implantés avec des îlots encapsulés d'animaux obèses, non obèses et avec des chambres vides. Des contrôles réguliers ont été ef fectués chez tous les animaux quant au gain de poids et aux glycémies. De plus, des mesures de 'insuline immunoréactive ont été effectués sur des échantillons de sang provenant de plusieurs animaux de chaque groupe. Toutes les souris, à l'exception de la moitié du groupe expérimental, ont été sacrifiées au $45 \mathrm{e}$ jour de l'expérience et des examens post-mortem ont été effectués. Les capsules contenant des îlots d'animaux non-obèses ont été retiré des souris obèses restantes et le gain de poids a été suivi pour une autre période de 45 jours. Après sacrifice de ces souris, des mesures de glycémies et des taux d'insuline ont été effectuées. - Les résultats de cette expérience ont montré que le gain de poids s'était stabilisé, que les glycémies et les taux d'insuline plasmatique des souris obèses s'étaient réduits au cours des 14 jours suivant l'implantation des chambres Millipores contenant des îlots pancréatiques des animaux non-obèses. Le gain de poids reprenait immédiatement et les glycémies et les taux d'insuline plasmatiques élevés ont été trouvés 45 jours après l'ablation des chambres de diffusion Millipore. - Les résultats de cette étude nous amènent aux conclusions suivantes: 1. L'obésité spontanée qui se développe chez la souris ayant une obésité héréditaire résulte d'une carence relative ou absolue d'un ou de plusieurs facteurs insulaires pancréatiques. 2. Ce facteur est originaire des îlots de Langerhans et il est capable de traverser les pores de $0.45 \mu$ des filtres Millipore. 3. La présence de ce facteur est nécessaire pour maintenir aussi bien une glycémie normale qu'une sensibilité à l'insuline et un métabolisme lipidique normaux.

Untersuchung der obob Maus nach Implantation von Langerhans'schen Inseln in Milliporekammern

Zusammenfassung. Isolierte Langerhans'sche Inseln normalgewichtiger Geschwister wurden in Millipore-Kapseln in die Peritonealhöhle von obob Mäusen implantiert. Als Kontrollen dienten $o b o b$ Mäuse, denen von obob erhaltene Inseln oder leere Milliporekammern implantiert wurden und normale Tiere, die entweder. Inseln von $o b o b$, von Kontrolltieren oder leere Kammern trugen. In regelmäßigen Abständen wurden Körpergewicht und Blutzuckerkonzentration kontrolliert. Außerdem wurden bei dieser Gelegenheit Blutproben aller Tiere zur radioimmunologischen Bestimmung der Insulinkonzentration gepoolt. Nach 45 Tagen wurden, mit Ausnahme der Hälfte der mit Normalinseln implantierten $o b o b$ Mäuse, sämtliche Tiere getötet. Bei den überlebenden $o b o b$ Mäusen wurden die von Normaltieren erhaltenen Langerhans'schen Inseln samt Millipore-Kapseln entiernt und die Beobachtung weitere 45 Tage fortgeführt. Es zeigte sich, daß die Implantation normaler Inseln in $o b o b$ Mäusen innerhalb von 14 Tagen zu einer Stabilisierung des Körpergewichts und zu einem Abfall der Blutzucker- und Insulinkonzentrationen führte. Nach Entfernung der Kapseln erfolgte ein erneuter Gewichtsanstieg und 45 Tage nach dieser letzten Operation waren Blutzucker und Insulinkonzentrationen wieder erhöht. - Die Resultate lassen folgende Schlüsse zu: 1. Das Spontanauftreten des obes-hyperglykämischen Syndroms der obob Mäuse ist auf den abolsuten oder relativen Mangel eines in den Langerhans'schen Inseln ent. haltenen Faktors zurückzuführen. 2. Diese Substanz diffundiert durch die $0.45 \mu$ weiten Poren der MilliporeMembran. 3. Dieser Faktor gewährleistet die Aufrechterhaltung eines normalen Glucose- und Fettstoffwechsels sowie einer normalen Insulinempfindlichkeit.

Key-words: Spontaneous diabetes, mutation $a b o b$, diabetes in mice, obesity in mice, implantation, transplantation, millipore filters, pancreas, insulin.
On longterm diet restriction, the obese-hyperglycemic mouse becomes sensitive to insulin, the islets decrease in size and number of cells and life span is lengthened (Lane and Dickie, 1958). The glucose level of the blood will be reduced, but not to the normal level observed in non-obese mice. The obese-hyperglycemic mouse, on limited food intake, still appears obese even when weight is comparable to controls 
(Mayer, 1960). Alloxan treatment of obese mice produces a transient lowering of blood sugar levels and causes an increase in granulation of the beta cells, but produces a degranulation in normal sibling (Solomon and Mayer, 1962).

Adipose tissue from obese mice shown hypertrophy and hyperplasia of individual fat cells (Hausberger, 1959). It was observed that adipose isografts, made between obese and normal littermates, take on the characteristics of the host and not the donor. This would appear to indicate that the metabolic defect found in obese adipose tissue is dependent upon some extra-adipose factor and not inherent in the fat cells.

Hausberger (1958) demonstrated that parabiosis of the hereditary-obese mouse with a non-obese littermate suppressed, and in some cases, prevented weight gains beyond pre-union levels. After separation, all obese parabionts gained weight rapidly, indicating that some factor which can be transmitted by successful parabiosis is missing in the hereditary-obese mouse. The fact that subtotal and partial pancreatectomy in the obese mouse reduces insulin levels, but fails to reduce obesity and weight gains (Mayer, et al., 1953) leads to the hypothesis that the pancreas may be involved in the production of the lipostatic factor.

Further evidence for this theory was obtained when islets implants from normal littermates were transferred to obese mice (Strautz, 1968). The blood sugar levels, plasma insulin concentration, and weight gains were reduced in these mice, while no effect was seen in non-obese mice which received obese islets.

The absence of such an islet factor in fat mice has been postulated by several authors (Hausberger, 1958; Mayer and Thomas, 1967; Strautz, 1968), although to date, no one has conclusive proof for its humoral characteristics or origin. The following study was designed to reexamine this problem by repeating an earlier experiment (Strautz, 1968) on islet implants.

\section{Materials and Methods}

Obese and non-obese mice of the inbred strain C57/ $\mathrm{BL} / 6 \mathrm{~J}$ were weaned, separated according to sex at five to six weeks and separated into groups as indicated in Table 1 a. Blood was taken, at seven weeks, via the tail vein from each animal for glucose and insulin determination, after which each received intraperitoneal implants of sealed millipore chambers containing either: a) 200-250 (approximately) isolated islets from the pancreas of non-obese mice, b) $200-250$ (approximately) isolated islets from the pancreas of obese mice, or e) no tissue (empty chambers). The obese mice with islets from non-obese were the experimental group and the mice of all other groups regarded as controls. The weight was checked daily for 45 days and blood withdrawn for glucose and insulin levels at 7, 14, 30 and 45 days post-implantation for each animal. Blood glucose levels were determined for each animal, insulin levels on pooled blood samples from each group.

Source and care of mice. All mice used in this study originated from a single breeding pair, heterozygous for the obese gene $(+\mid o b)$ and obtained from the Jackson Labs, Bar Harbor, Maine, 1965. The litters were weaned at about 5 weeks of age and separated according to sex and later according to phenotype. Mice homozygous for the obese gene $(o b / o b)$ could be distinguished about this time by the excess accumulation of abdominal fat. The heterozygous $(+/ o b)$ and homozygous $(+/+)$ non-obese cannot be differentiated.

All animals were housed in plastic lab cages at relatively constant temperature $\left(24^{\circ} \mathrm{C}\right)$. The mice had free access to food, in the form of Purina lab pellets and tap water. Greens were given once a week and a special vitamin supplement added to the drinking water every other week (Protovit-Roche Pharmaceuticals).

Technique of islet isolation. Pancreatic islet isolation was performed in obese and non-obese donors by following, with a few modifications, the procedures described by Kostianowsky and Lacy (1966) for the rat. All operations were performed with the aid of $10 \times$ magnification of a binocular dissecting microscope. Animals at seven weeks of age were anesthetized with Nembutal (Abbott Laboratories) and secured to an operating board in a supine position. The skin in the abdominal area was cleaned with $70 \%$ alcohol. All instruments were sterilized by immersion in a tincture of zephiran chloride. A mid-line incision was made through the skin, muscle, and peritoneal lining extending approximately $3-4$ centimeters caudal to the sternum. The skin was retracted and the intestines moved to expose the diffuse pancreatic tissue. The duodenum was clamped at the pyloric sphincter and below the level of the pancreatic ducts entrance. The upper elamp also occluded the bile duct. The acinar tissue of the pancreas was disrupted by injecting approximately $5 \mathrm{ml}$ of Hank's solution into the duodenum. This method was used since, in the mouse, the exocrine pancreas drains directly into the duodenum through several pancreatic ducts. The body and tail of the pancreas were removed, trimmed, and washed in two changes of Hank's solution. The pancreas was then placed in a freshly prepared solution of $1 \%$ collagenase (Nutritional Biochemical Corporation, Cleveland, Ohio) and cut into small pieces with scissors. The tissue was stirred in a closed weighing bottle using a magnetic stirrer and incubated 20 min at $37^{\circ} \mathrm{C}$.

After incubation of the pancreas with collagenase, the mixture was diluted with 15 to $25 \mathrm{ml}$ of Hank's solution in a conical, graduated centrifuge tube and allowed to settle for one minute. The intact islets would settle to the bottom of the cylinder during this interval. The supernatant was removed with a syringe and needle and discarded. The sediment containing the islets was resuspended in Hank's solution and allowed to settle for $30 \mathrm{sec}$. This procedure was repeated for a total of eight times using cold Hank's solution 
for the last four suspensions. The sediment remaining was diluted with Hank's solution, transferred to a glass dish surrounded by an ice bath, and examined with a dissecting microscope.

The unstained islets could be recognized easily under a dissecting microscope when viewed aginst a black background. They appeared as free, round or ovoid structures with a greyish-white to brownish-red color. A small glass loop, which was slightly larger than the diameter of the islets, was used to transfer individual islets into another dish containing cold Hank's solution. Approximately $100-120$ islets could be transferred within a period of $30 \mathrm{~min}$. The final transfer of islets into the diffusion chambers was accomplished by using a $0.5 \mathrm{ml}$ syringe.

Diffusion chambers. To retain the islet cells, diffusion chambers were constructed of nylon reinforced Millipore membranes with a $0.45 \mu$ pore rating and a thickness of $100 \mu \pm 10 \mu$. Squares of slightly less than one $\mathrm{cm}$. were cut and the edges of two pieces were approximated. Three sides were sealed using a thin film of MF cement (formulation No. 2). The assembled chambers were sterilized by formalin vapor for several hours and then filled with approximately $200-250$ isolated pancreatic islets from either obese or nonobese mice. The remaining side of the chambers were sealed with MF cement and kept in sterile Hank's solution for not more than $10 \mathrm{~min}$ before implanting.

Method of implanting. Within a few hours following the initial blood glucose and plasma insulin determinations, obese and non-obese mice were anesthetized with Nembutal and secured, in a supine position, to an operating board. After cleaning the abdominal area with $70 \%$ alcohol, a mid-line incision was made just large enough to admit the diffusion chamber. The abdominal muscles and fascia were separated and the chambers inserted among the intestinal coils. The wound was closed using a single autoclip (ClayAdams), which was removed at 5 days post-operation. The animals were allowed to recover under a warming lamp for a few hours.

Weight and blood glucose determination. All animals were kept for 45 days and weighed, on a dietary balance, daily at approximately the same time of day. Blood was taken at mid-day from the tail at $0,7,14$, 30 , and 45 days. Approximately $0.15 \mathrm{ml}$ was used for both glucose and insulin levels. The blood glucose concentration of all animals was determined by a micro-modification of the Somogyi-Nelson method. Duplicate determinations were done on $0.05 \mathrm{ml}$ of whole blood and group averages compared using a standard "T" test.

Immunoassay for insulin. The insulin level was determined by an immunoassay which consisted of a double antibody system (Morgan and Lazarow, 1962). The theory behind this method of determination is based on the observation that ${ }^{131} \mathrm{I}$ tagged insulin (Abbott Laboratories, Oak Ridge, Tennessee) can be bound in vitro with anti-insulin serum obtained from immunized guinea pigs (AIS-GP, obtained from Pentex, Kankakee, I11.) to form a soluble complex. This complex is then quantitatively precipitated by antiguinea pig serum antibody obtained from immunized rabbits (AGPS-R obtained from Fisher Scientific, Silver Spring, Md.). When ${ }^{131}$ I insulin is used as a tracer, the amount of radioisotope present in the precipitate is a function of the concentration of unlabeled insulin present in the reaction mixture. The difference in the percent of ${ }^{131} \mathrm{I}$ tagged insulin precipitated, when varying amounts of unlabeled insulin were added, forms the basis of the quantitative assay.

A mouse insulin preparation for immunoassay has not yet been described and the mouse insulin values stated are approximations expressed in beef equivalents.

Histological examination. At 45 days, all mice except one-half the experiment group were sacrificed and the endogenous pancreas and Millipore filter chamber, with contents, preserved in Bouin's fixative. Histological preparation were made and stained by the Azan technique (Romeis, 1948).

Supplementary studies. The remaining animals in the experimental group of obese mice were anesthetized and the diffusion chamber, containing non-obese islets, removed and prepared as above. The obese mice were then followed by daily weighings for an additional 45 days, after which blood glucose and insulin levels were determined, the animal sacrificed, and its pancreas preserved for histological observation.

\section{Results}

The results summarized in Tables $\mathbf{1}-\mathbf{3}$ are based on 88 animals that survived the initial implantation of Millipore diffusion chambers. Each figure (except insulin levels) represents the arithmetic mean of group samples \pm standard error.

The body weight for the obese and lean mice are given in Table 1 a for 45 days following implantation of the Millipore chambers. No significant difference in weight exists, at any interval, between the groups of non-obese mice containing encapsulated obese islets, non-obese islets or empty chambers $(P=>0.05)$.

Apparently the animals own islet tissues maintain a balanced carbohydrate-lipid metabolism for normal weight gains. When comparing groups of obese mice with encapsulated obese islets and obese mice with empty diffusion chambers it was observed that there was a significant and uniform weight gain. The hypothetical factor necessary to prevent this gain in weight is lacking in the islets of the obese mice. The obese mice with non-obese encapsulated islets, however, show a significant reduction in weight gain after 7 days $(P=0.003)$, when compared to other obese groups. This weight gain in obese with non-obese islets parallels the minimal weight increase of all non-obese groups. As was true in a previous experiment (Strautz, 1968), the prior accumulation of abdominal fat re- 
mained, even though there was a stabilization in weight gains.

45 days post-implantation, four obese mice from the group containing encapsulated non-obese islets, were anesthetized with Nembutal and restrained onto an operation board. The abdominal walls, of the obese mice were opened surgically, as described in material and methods and the Millipore diffusion chamber removed from its' vascular connective tissue bed in the host's abdominal cavity. The capsules were prepared for histological examination as described previously. The surgical wounds of these obese mice, were closed, using wound clips and the mice placed under a warming lamp until they had recovered. As shown in table $1 \mathrm{~b}$, the weight gains returned almost immediately after removal of the diffusion chamber and continued to rise up to day 90 (45 days after removal of chamber) the elevated glucose levels lead to glucosuria, symptoms pointing to a similarity between the obese mouse and the maturity onset diabetes in man. The hyperglycemia, noted in the obese mouse with non-obese islets was reduced at day 14 and remained significantly lower through day $45(P=<0.001)$. At day 30 through day 45 it compared statistically with levels shown in non-obese groups $(P=>0.25)$. The glucase concentration in obese mice after the normal islets were removed did not, however, approach the level observed in other obese groups at 45 days. The importance of this fact is noted in the similar responses in weight gains and insulin levels (see below) after the encapsulated normal islets had been removed from the obese mice.

Immunoreactive insulin was determined in obese and lean mice at various intervals, as is shown in

Table 1 a. Weight gains in obese and normal mice following implantation of millipore diffusion chambers

\begin{tabular}{|c|c|c|c|c|c|c|c|c|}
\hline \multirow[t]{2}{*}{ Group } & \multirow{2}{*}{$\begin{array}{l}\text { Islet } \\
\text { implants }\end{array}$} & \multirow[b]{2}{*}{$\#$ of Mice } & \multicolumn{6}{|c|}{ Average weight in grams - days following diffusion chamber implantation } \\
\hline & & & 0 & 7 & 14 & 28 & 45 & $\%$ increase \\
\hline Obes & non-obese & 8 & $29.1 \mp 0.5$ & $30.0 \mp 0.5$ & $29.8 \mp 0.5$ & $31.3 \mp 0.8$ & $33.6 \mp 0.9$ & 13.9 \\
\hline Obese & obese & 9 & $31.0 干 0.5$ & $34.6 \mp 0.5$ & $38.6 \div 0.9$ & $43.3 \mp 1.0$ & $50.9 \mp 1.3$ & 39.1 \\
\hline Obese & none & 11 & $30.5 干 0.5$ & $33.0 干 0.8$ & $37.7 \mp 0.7$ & $42.5 \mp 0.9$ & $50.4 \mp 1.2$ & 39.5 \\
\hline Non-obese & obese & 12 & $20.8 \mp 0.4$ & $21.7 干 0.5$ & $22.5 干 0.5$ & $23.4 \mp 0.6$ & $25.0 \mp 0.6$ & 16.8 \\
\hline Non-obese & non-obese & 11 & $20.0 干 0.6$ & $19.7 干 0.6$ & $21.1 \mp 0.5$ & $22.9 \mp 0.5$ & $24.9 \mp 0.6$ & 19.7 \\
\hline Non-obese & none & 12 & $21.1 \mp 0.4$ & $21.8 \mp 0.5$ & $22.4 \mp 0.7$ & $22.9 \mp 0.6$ & $24.6 干 0.6$ & 14.2 \\
\hline
\end{tabular}

Table $1 \mathrm{~b}$. Weight gains in four obese mice following removal of diffusion chamber containing non-obese islets

\begin{tabular}{|c|c|c|c|c|c|c|c|c|}
\hline \multirow[t]{2}{*}{ Group } & \multirow{2}{*}{$\begin{array}{l}\text { Islet } \\
\text { implant }\end{array}$} & \multirow[b]{2}{*}{ \# of Mice } & \multicolumn{6}{|c|}{ Average weight in grams - days following removal of chamber } \\
\hline & & & 0 & 4 & 18 & 39 & 45 & $\%$ increase \\
\hline Obese & non-obese & 4 & $33.6 干 0.9$ & $34.8 \mp 0.5$ & $39.0 \mp 0.9$ & $44.8 \mp 2.2$ & $45.5 \mp 2.1$ & 23.5 \\
\hline
\end{tabular}

at which time the animals were sacrificed and blood taken for glucose and insulin level determinations. The total weight gain was still lower at 90 days then the other two obese groups (those with islets and empty chambers) at 45 days. These obese control groups had $39.1 \%$ and $39.5 \%$ increase in weight during the 45 days following implantation, whereas the obese group (with non-obese islets) gained only $23.5 \%$ after the chambers had been removed. The increase in weight between 45 and 90 days (after removal of diffusion chambers) was seen as additional accumulation of abdominal fat.

Blood glucose levels both before and after islet implantation are shown in Table 2. The levels were similar in all non-obese groups throughout the experiment $(P=>0.2$ ), but rose with each determination in obese mice containing obese islets and empty chambers. These results agree with previous published findings (Wrenshall, et al., 1955) in showing higher glucose levels in mature obese mice. After the fourth month
Table 3. Insulin levels were determined on pooled group samples because of the volume of plasma needed to conduct this test. The concentration of insulin varied between 42 and $125 \mu$ units $/ \mathrm{ml}$ in all non-obese mice. The average in these groups was not significantly different $(P=>.09)$ and was within limits, described for a normal mouse (Christophe et al., 1959). The immunoreactive insulin in obese containing non-obese islets remained low, but returned to a high value, comparable to other obese mice, after the diffusion chamber, with normal islets, had been removed. The insulin levels in the other obese groups, i. e., with obese islets and empty chambers, increased at each interval, indicating the pattern of insulin resistance which develops in mature obese mice (Bleisch et al., 1952). Similar responces are noted in human subjects after the onset of severe obesity (Bagdade et al., 1967). To test whether the obese with non-obese encapsulated islets, were insulin sensitive, four animals were injected with regular insulin (beef) ( 5 units $\mathrm{kg}$ body weight), an 
amount sufficient to cause convulsions in normal nonobese mice. The blood glucose concentration had fallen by $43 \%$ after one hour, as compared to levels in these same mice before the insulin injection. This quantity of insulin has been shown to produce an elevation in an already high blood sugar in obese mice (Mayer et al., 1951). In this case the minimal reduction of hyperglycemia, in obese mice shown to be insulin resistant, is probably masked by the concomitant rise initiated, during the stress of handling and injection.

Post-mortem examinations revealed that the diffusion chambers had become enclosed in a well vascularized fibrous connective tissue envelop. There was no evidence of disruption of the cell retaining Millipore

\section{Discussion}

Factors responsible for preventing excessive weight, hyperglycemia and hyperinsulinism in normal mice can be transmitted to obese mice by intraperitoneal implants of pancreatic islets taken from non-obese littermates, as shown in previous experiments (Strautz, 1968). Results of the present work summarized in Table 1 a, clearly show that obese mice implanted with nonobese islets in Millipore diffusion chambers, did not have the weight gains recorded for obese mice with empty chambers. At the same time glucose and insulin levels of the blood were reduced to limits observed in non-obese mice (Tables 2 and 3 ). This evidence sug-

Table 2. Blood glucose levels in obese and non-obese mice following implantation of mallipore diffusion chambers

\begin{tabular}{|c|c|c|c|c|c|c|c|c|}
\hline & & 津 of mice & 0 & 7 & 14 & 30 & 45 & $90^{\mathrm{c}}$ \\
\hline Obese & non-obese & 8 & $180.3 \mp 4.5$ & $172.3 \mp 9.3$ & $152.9 \mp 7.3$ & $135.4 \mp 4.9$ & $130.8 \mp 3.9$ & $268.8-19.3$ \\
\hline Obese & obese & 9 & $160.6 \mp 4.7$ & 190.7干13.1 & $225.3 \mp 14.6$ & $252.1 \mp 12.2$ & $293.276 .7^{\mathrm{a}}$ & \\
\hline Obese & none & 11 & $159.2 \mp 5.2$ & $195.6 \mp 6.9$ & $228.1 \mp 12.6$ & $269.9 \mp 14.7$ & $304.1 \mp 13.6^{\mathrm{a}}$ & \\
\hline Non-obese & obese & 12 & $124.3 \mp 2.3$ & $123.1 \div 3.1$ & 127.373 .2 & $134.7=2.9$ & $129.2=4.0^{\mathrm{b}}$ & \\
\hline Non-obese & non-obese & 11 & $126.2 干 2.7$ & $129.4 \mp 2.9$ & $130.7 \mp 2.4$ & 127.574 .3 & $129.2 \mp 3.1^{\mathrm{b}}$ & \\
\hline Non-obese & none & 12 & $129.6 \mp 3.4$ & $135.3 \mp 3.3$ & $130.8 \mp 2.3$ & $131.8 \mp 2.3$ & $128.473 .0^{\mathrm{b}}$ & \\
\hline
\end{tabular}

a $P=0.06$ at each interval.

b $P=0.2$ at all intervals.

c 45 days after removal of chamber from 4 mice

Table 3. Immuno reactive insulin levels of pooled samples from groups of obese and non-obese mice following implantation of millipore diffusion chambers

\begin{tabular}{|c|c|c|c|c|c|c|c|c|c|}
\hline \multirow[t]{2}{*}{ Group } & \multirow{2}{*}{$\begin{array}{l}\text { Islet } \\
\text { implant }\end{array}$} & \multirow[b]{2}{*}{$\#$ of Mice } & \multicolumn{7}{|c|}{ Insulin levels Units/ml } \\
\hline & & & 0 & 7 & 14 & 30 & 45 & $\bar{x}$ & 90 \\
\hline Obese & non-obese & 8 & 125 & 85 & 58 & 90 & 68 & 85.2 & 325 \\
\hline Obese & obese & 9 & 90 & 120 & 220 & 380 & 475 & - & - \\
\hline Obese & none & 11 & 88 & 125 & 190 & 280 & 390 & - & - \\
\hline Non-obese & obese & 12 & 64 & 125 & 100 & 92 & 80 & 92.2 & 一 \\
\hline Non-obese & non-obese & 11 & 60 & 85 & 4.2 & 75 & 82 & 68.8 & - \\
\hline Non-obese & none & 12 & 43 & 68 & 120 & 76 & 72 & 75.6 & - \\
\hline
\end{tabular}

chambers and all contained granulated cells. Staining revealed cell constituents within the capsules differing from normal islets. The predominant cell type observed, was large (about $20 \mu$ ) and contained purple staining granules. There was little increase in the fibrous elements around groups of cells and an occasional pancreatic duct could be identified among the other components.

No morphologic or pathologic changes could be seen in the endogenous pancreatic tissue taken from non-obese mice. Obese mice did, however, reveal hypertrophy and hyperplasia of the islets, as seen after the onset of this syndrome in previous studies. No differences in the size of islets was noted between obese groups but an occasional mitotic figure was seen in obese mice with implanted obese islets or empty diffusion chambers. gests that some component of the non-obese pancreas produces and releases the factors capable of influencing fat deposition, probably through it's control on glucose metabolism. If this observation is analogous to the normal process of fat deposition, then the influence may be mediated either by direct action on the peripheral tissue as postulated by Mayer and Thomas (1967), or indirectly by its control of insulin response to blood glucose loads as suggested by Paulsen, et al. (1968).

The data presented in Table 1a also implies that substances originating in the non-obese pancreatic islets are capable of passing through $0.45 \mu$ pores of the Millipore membrane and influencing weight gains in the obese mice. Post-mortem gross and microscopic examinations of Millipore chambers from obese mice gave no evidence of disruption or loss of ability to re- 
tain cells. The results presented here show that diffusable factors, elaborated by non-obese pancreatic islets play a major role in reversing, and probably preventing, conditions responsible for the obese state in mice.

The pancreatic source of this factor was suspected after the observation that islets in obese mice were deficient in silver positive alpha $\left(a_{1}\right)$ cells (Hellman, 1961). Although no specific function has been attributed to these cells, evidence from other work suggest that the $a_{1}$ cell is the source of a third pancreatic factor (Epple, 1965; Hellman and Lernmark, 1969). The present study lends support to the existence of another hormone elaborated by islet cells, although there is no direct evidence, to indicate which cells are involved. Evidence that the primary defect in obese mice is not caused by hypersecretion of beta (insulin) or $a_{2}$ cells (glucagon) is provided by experiments in which non-obese mice received islets from obese animals. In such experiments the weight gains of normal mice were not affected by the presence of obese islets (Table 1a). The levels of glucose and insulin in nonobese with obese islets, remained low, throughout the study, as compared to other non-obese mice (Tables 2 and 3 ).

The experiments described in this thesis do not support the suggestion of Clark, et al. (1956), that the development of obesity in the hereditary obese mouse is caused by an excess secretion of a "hyperglycemiaglycogenolytic" factor from the pancreas of these animals. The experiments in Clark's study, which indicated that the pancreas of obese mice released abnormal quantities of a glucagon-like substance, involved substance, involved the injection of obese pancreatic extract into other obese animals. The pancreatic extract caused the hyperglycemia to increase; a reaction identical to that seen when insulin is injected into these obese-hyperglycemic mice. Injection of this same extract into non-obese mice lowered the blood sugar; an anticipated reaction, since earlier workers observed elevated levels of pancreatic insulin in the obese mouse (Wrenshall, et al., 1955). If in fact the pancreas of obese mice release a hyperglycemic factor, then transplants of these islets into normal mice should elevate the blood sugar. As seen in Table 2, no such elevation occurred at any interval, even though the islets in diffusion chambers remained viable. It is probable that glucagon plays a less important role in mice than man, since injections of this hormone, into well-fed and fasted non-obese mice, cause an insignificant rise in blood glucose (Shull and Mayer, 1956). There is, then, no reliable evidence to support the theory that the obese syndrome could be caused by a hyperglycemic factor. Chronic studies might well show that glucagon could lower weight gains by decreasing food intake in the obese. In this case the error would be in a high setting for glucose response in the hypothalamic satiety centers.

It would, therefore, seem probable that the obese state in mice ensues from the lack of some factor.
Evidence in support of this theory is provided by Hausberger's parabiosis experiment (1958). Hausberger found that the weight gains of hereditary obese mice, in parabiotic union with a non-obese littermate, were suppressed until the two mice were separated, when all obese parabionts gained weight rapidly. Both my earlier experiment and the present work support this thesis, that a factor is missing in the obese mouse. Moreover, the study described in this paper would imply the origin of this factor is the cells of the nonobese pancreatic islets. Removal of the capsule, containing non-obese islets, could be compared to separation of Hausberger's parabionts. As seen in Table $1 \mathrm{~b}$, weight gains resumed immediately in the obese after removal of the encapsulated non-obese islets containing the factor responsible for suppression of fat deposition.

Obese mice did not, however, lose weight but retained excess abdominal fat, deposited before implantation of Islets. This observation was also noted in previous experiments (Strautz, 1968). It is possible that additional factors are responsible for the obese state and these substances originate from a source other than the pancreas. The factor described in the present study can only regulate the balance between lipogenesis and lipolysis, having no effect on the volume of fat mass which is probably also genetically determined.

There is indirect evidence to suggest that the primary action of this factor is on lipid metabolism. The first recognizable symptoms in weaning obese mice are insulin tolerance and excess fat deposition, each identified several weeks before hyperglycemia and hyperinsulinism are apparent (Westman, 1968). That the imbalance in fat metabolism precedes the other characteristies associated with this obesity in mice gives support to Mayer's (1967) proposal that this factor is directly involved in lipogenesis in adipose tissue. He suggests that this factor represses glycerokinase activity in adipose and other extrahepatic tissues. This enzyme allows the cells in other tissue to reutilize glycerol, released by lipolysis. In the absence of glycerokinase activity, adipose tissue must depend upon glycerol phosphate, provided by glucose catabolism, to resynthesize fats. Lipogenesis, in adipose tissue, is normally controlled by the levels of glycerol phosphate and indirectly of glueose. Although the rate of conversion from glucose to glycerol phosphate is reduced (Christophe et al., 1961), the rate of glycerol incorporated into glycerol phosphate in adipose tissue is elevated (Fried and Antopol, 1960). Simultaneous elevation of glycerokinase activity is noted in adipose tissue of obese mice (Loechaya et al., 1963). The lack of some pancreatic islet factor, which normally suppresses glycerokinase activity in extrahepatic tissue, could lead to increased concentrations of glycerol phosphate and at the same time, decreased glucose uptake. As a result, insulin peripheral antagonism develops with a secondary hyperplasia and hyper- 
trophy of islets in response to the continuous hyperglycemia. Many of the other pathophysiologic characteristics of obese mice, described earlier, would be secondary responses to the abnormal lipid and glucose metabolism in adipose tissue.

The above suggestions do not, however, exclude the possibility that the obese mouse is insensitive to its own insulin. This ineffectiveness of endogenous insulin, in the obese, would prevent proper function of the satiety and feeding center in the brain resulting in hyperphagia, at the same time reducing peripheral action of insulin on adipose tissue. The results obtained in the present study indicate that implanted non-obese islets supply hypoglycemic factors capable of maintaining normal carbohydrate and lipid metabolism in the obese and probably decreasing food intake by effecting satiety center response to glucose utilization. This proposal does not explain why injected beef insulin fails to lower glucose levels in the obese mice (Mayer et al., 1951), unless some additional factor is superimposed on the peripheral use of insulin.

The action of an alpha $\left(A_{1}\right)$ factor on insulin release (Hellman, and Lernmark, 1969) is compatible with the results of the present study, but exactly how this action is mediated, beyond its direct effect on inhibition of insulin elaboration is difficult to determine with the present knowledge.

\section{References}

Bagdale, J.D., Bierman, D.L., Porte, D., Jr.: The significance of basal insulin levels in the evolution of the insulin response to glucose in diabetic and non diabetic subjects. J. clin. Invest. 46, 1549-290 (1967).

Bleisch, V.R., Mayer, J., Diebie, M.M.: Familial diabetes mellitus in mice associated with insulin resistance obesity, and hyperplasia of the islands of Langerhans. Amer. J. Path. 28, 369-385 (1952).

Christophe, J., Dageuois, Y., Mayer, J.: Increased Circulating Insulin Like Activity in Obese-Hyperglycemic Mice. Nature 184, 61-62.

- Bernard, J., Mayer, J., Reynold, A.E.: Metabolism in vitro of adipose tissue in obese-hyperglycemic and goldthioglucose treated mice. I. Metabolism of glucose. J. biol. Chem. 236, 642-647 (1961).

Clarke, D.W., Wrenshall, G.A., Mayer, J.: Effects of pituitary growth hormone on the insulin and hyperglycemic-glycogenolytic factor extractable from the pancreas of obese-hyperglycemic mice. Nature 177, 1235 (1956).

Epple, A.: Weitere Untersuchungen über ein drittes Pankreashormon. Verhandl. Dent. Geo. Zool. 29, 459-470 (1965).
Fried, G.H., Antopol, W.: Alpha-glycerophosphate Oxidation in the tissues of obese-hyperglycemic mice and non obese controls. Fed. Proc. (Abstract) 19, 327 (1960).

Hausberger, F.X., Ramsay, A.J.: Parabiosis and transplantation experiments in hereditary obese mice. Anat. Rec. 130, 331 (1958).

- Behaviour of transplanted adipose tissue of hereditary obese mice. Anat. Rec. 135, 109-113 (1959).

Hellman, B.: The occurance of argyrophil cells in the islets of Langerhans of american obese hyperglycernic mice. Acta endocr. 36, 596-602 (1961).

- Lernmark, A.: Inhibition of the in vitro secretion of insulin by an extract of pancreatic alpha-1 cells. Endocrinology 84, 1484-1488 (1969).

Kostianovsky, M., Lacy, P.E.: A. Method for the Isolation of Intact Islets of Langerhans from the mammaliam Pancreas. Fed. Proc. (Abstract) 25, 377 (1966).

Lane, P. W., Dickie, M. M. : The effect of restricted food intake on the life span of genetically obese mice. J. Nutr. 64, 549-554 (1954).

Lochaya, S.N., Leboeuf, Mayer, J.: Adipose tissue metabolism of obese mice on standard and high fat diets. Amer. J. Physiol. 201, 23-26 (1961).

Mayer, J.: The obese-hyperglycemic syndrome of mice as an example of "Metabolic" obesity. Amer. J. clin. Nutr. 8, 712-718 (1960).

- Bates, M.W., Dickie, M.M.: Hereditary diabetes in genetically obese mice. Science 113, 746-747 (1951).

- Jones, J.: Hypercholestrolemia in the hereditary obesehyperglycemic syndrome of mice. Amer. J. Physiol. $175,339-342(1953)$.

- Thomas, D.W.: Regulation of food intake and obesity. Science 156, 328-337 (1967).

Morgan, C.R., Lazarow, A. : Immunoassay of insulin using a two-antibody system. Proc. Soc. exp. Biol. 110, $29-32(1962)$.

Paulson, E.P., Richenderfer, L., Ginsberg-Fellner, F.: Plasma glucose, free fatty acids and immunoreactive insulin in 66 obese children. Diabetes 17, 261-269 (1968).

Romeis, B.: Mikroskopische Technik. München: Oldenbourg 1948.

Shull, K.H., Mayer, J.: Analysis of blood sugar response of obese hyperglycemic mice and normal mice to hormones: Insulin, glucagon and epinephrine. Endocrinology (Abstract) 21, 396 (1956).

Strautz, R. L.: Islet implants : Reduction of glucose levels in the hereditary obese mouse. Endocrinology 83, 975979 (1968).

Westman, S.: Development of the obese-hyperglycemic syndrome in mice. Diabetologica 4, 141-149 (1968).

Wrenshall, G.A., Andrus, S.B., Mayer, J.: High levels of pancreatic insulin coexistent with hyperplasia and degranulation of beta cells in mice with the hereditary obese-hyperglycemic syndrome. Endocrinology 56 $335-340(1955)$.

Dr. R. L. Strautz

Department of Biology

The American University

Washington D.C. 20016/USA 